Gregory, Maughn Rollins \& La/verty, Megan Jane, eds. In community of inquiry with ann Margaret Sharp: childhood, philosophy, and education. New York: Routledge, 2018, Pp. 264.

félix garcía moriyón1 universidad autónoma de madrid, espanã orcid id: http:/ / orcid.org/0000-0002-3951-5728

\title{
a normative approach to philosophy for children
}

Twice this year, from January to May, I have attended academic activities related with Philosophy for Children (P4C), where speakers, both very familiar with the curriculum produced at the Institute for the Advancement of Philosophy for Children (IAPC) and with the whole project of philosophy for/with children, expressly referred the IAPC curriculum as "Lipman's curriculum." Each time, as in many similar situations before, I raised my hand so that I could intervene in the dialogue and my comment was as short as it was direct:

Please, you have made two partial or erroneous statements: first, $\mathrm{P} 4 \mathrm{C}$ is not a method, but a pedagogical proposal that involves much more than a method; second, it is not a contribution by Matthew Lipman, but by Lipman and Ann Margaret Sharp2 together.

This misunderstanding is as old as the proposal itself.

Thus, when I discovered this new book, I was very grateful to the editors, Maughn Rollins Gregory and Megan Jane Laverty, for their effort and their accomplishment: I realized that it was a noteworthy contribution to a better understanding of the philosophical and educational work of the IAPC from 1970 until 2010. Without the contribution of Ann it is not possible to understand the "childish" turn of philosophy and even less its impact on education in the third part of 20th Century.

Ann came to our city, Madrid, for several consecutive years, in a completely disinterested way, to give one-week courses to train teacher trainers. These proved to be decisive courses for the dissemination and implementation

1 E-mail: felix.garciamoriyon@gmail.com

2 From here, I'll just use Ann to mention her. 
Gregory, Maughn Rollins \& Laverty, Megan Jane, eds. In community of inquiry with ann Margaret Sharp: childhood, philosophy, and education. New York: Routledge, 2018, Pp. 264.

of the program in Spain. Her first teacher training workshop was in July 1988, and was attended by around 25 philosophy teachers from high schools and universities. Ann, whose educational talent is well known, inspired ten of them to join the project, and they subsequently became the nucleus of the Spanish Center of Philosophy for Children. From that time onward, I collaborated with Ann in giving teacher training courses in several countries - a collaboration truncated by her early passing.

Gregory and Laverty's book enables readers to learn more about Ann's contribution to $\mathrm{P} 4 \mathrm{C}$ and to go deeper into the program. Many of us of a certain age are well informed about Ann's excellent work in program dissemination and teacher training. This anthology of texts and essays reminds us that her theoretical work was also very important. The structure seems brilliant to me: Gregory and Laverty divide the book into seven parts, each dedicated to a theme: pragmatism; philosophy of education; ethics and personality; feminism and childhood; religion, spirituality and aesthetics; caring thinking and emotions; and, finally, political and social education. In each of them we find one or two of Ann's articles. Together, these articles represent the range and depth of her thought and allow us to realize her intellectual and educational achievements. In addition, each section begins with an article by a P4C expert who knew Ann well, dialoguing with her thought and action. The final index of names and concepts is a very useful tool to find specific information. All those texts-Ann's articles and the contributions of commentators-offer a fruitful field of reflection.

The whole book offers a valuable and well-deserved tribute to Ann's contribution to the founding and growth of P4C around the world. However, from my point of view, while very important, that is not what interests me the most. The book has allowed me to go deeper into some fundamental questions of the educational proposal of P4C. There are three questions that I will highlight in this review. First, the importance of doing philosophy in education, and her specific understanding of the concept of philosophy and philosophizing. Second, the normative character that Ann gives to caring 
thinking and to democracy, which is linked to her commitment to fallibilism. Third, I am very interested in the role of Nietzsche in her innovative approach to teaching and the essence of education. I address the three questions in this order. Having considered the three questions, I conclude this review essay with some reflections on Ann and the spiritual dimensions of P4C. I conclude by addressing this topic because it best encapsulates Ann's sense of the transcendent aspirations inherent in the community of philosophical inquiry.

Perhaps the articles that have caused me to clarify my reflections the most are those at the beginning: first, the good personal and intellectual biography of Ann by Laverty and Gregory and second, the conversation that Peter Shea has with Ann. Ann's pedagogical experience in her early years at the Shaker Village Group makes very clear her choice of the latter of what Phil Cam calls, quoting Rorty, “capital P Philosophy and lowercase $p$ philosophy” (p. 30). Sharp understands from the beginning of her professional life that philosophy must be embedded in the everyday life of people, becoming incarnated and exoteric; it must not remain centered on the Academy and on inter-academic dialogue. This is by no means an undervaluation of academic philosophy, but a personal effort to bring its rigor and conceptual richness to everyday life, which is present in all people and at all ages. It is not surprising that Ann found Lipman's proposal so early in her career, because in the end you only find what you are looking for. Clearly, P4C was what Ann was looking for and it explains her affinity with Lipman (Lipman and Kennedy, 2011).

In the case of Sharp, her commitment to a more embodied philosophy, more at street level, is influenced by American Pragmatism. The influence of John Dewey is evident, for whom philosophical reflection was directly related to people's daily experience and should be expressed in formal education. Other later influences are along these same lines, such as Martha Nussbaum or Simone Weil-I found the article written by Ann and Gregory on the French philosopher revelatory. Ann's interpretation of Weil's thought reflects very well that one's personal choice for a philosophy is attached to one's everyday life. She writes: 
Gregory, Maughn Rollins \& Laverty, Megan Jane, eds. In community of inquiry with ann Margaret Sharp: childhood, philosophy, and education. New York: Routledge, 2018, Pp. 264.

Only when a woman reads her daily experiences in terms of a selfresponding to the world does she discover both her powers and the limits of her power. A feminist philosophy of education is not derived from predetermined truths, but fashioned from a dialectic between the experience of women and men past and present. (p. 157)

Bringing philosophy into the classroom implies highlighting something specific to philosophy: a mental activity that shows three main features, 1) analyzing and reasoning qualities, 2) qualities detecting ambiguities, uncertainty and borderline explorations, and 3) qualities of moving smoothly from theory to practice and vice versa (Rondhuis; 2005). It is also an activity that focuses on very general concepts, such as justice, goodness, being, beauty, self, identity, reality, appearance-concepts that are never clear enough although we use them constantly. They are part of our day-to-day life and are important and relevant, that is why we are interested in talking about them. This makes it possible to develop and manage broad frames of reference, what we might also call worldviews, establishing connections between theory and practice or real-life experiences. Most importantly, trying at all times to figure out the kind of people we want to be and the kind of world we want to live in.

P4C's educational proposal is novel in the sense that it proposes philosophical activity as the central nucleus of a truly transformative education. Hardly anyone had dared to suggest that young children could do philosophy, much less academic philosophers (some are still reluctant to accept it). It is less original, but also fundamental, to have linked philosophical reflection to the community of inquiry, with direct and explicit influences from Charles Peirce and John Dewey, but also from different trends of Progressive education. The concept is central, but it is worth insisting on something that is the cause of discussion within P4C's own community: it is a community of philosophical inquiry, and the adjective philosophical is not accidental, but essential. It is important because other school disciplines also claim communitarian and cooperative models of learning, a powerful pedagogical approach that exists long before Lipman and Sharp's proposal and exists beyond philosophy. Even in the teaching of philosophy, we can find brilliant examples in Socrates, in the Epicureans or in medieval schools, with Abelard as its initiator. 
And in this field, Ann's contribution is important. She always insisted, in the training courses (pp. 88s.), that teachers who work with children and teenagers must develop a philosophical sensitivity by becoming familiar with the contributions of philosophy throughout history. Overcoming a false dichotomy, Ann maintained that one does not make philosophy without knowing philosophy and one does not know philosophy if one does not make philosophy and she defends this with a serious reflection on what it means to transform classrooms into communities of philosophical inquiry. The whole book bears witness to this, especially the parts that explore ethics (part III), caring thinking (part VI) and socio-political education (part VII). Ann's articles included in the book and the contributions of Laurance Splitter, Richard Morehouse and Jen Glaser are profound and suggestive.

If there is one thing that seems fundamental to me, it is the confirmation that Sharp is proposing a normative, not purely descriptive, concept of the community of philosophical inquiry: in an interesting and powerful exercise included at the beginning of Ethical Inquiry (Lipman-Sharp, 1995, chap.1, Leading idea 1), some cognitive and social skills are suggested that allow participants to delve deeper in what a community of inquiry implies. Ann emphasizes the normative dimension in her essay, "A letter to a novice teacher," reprinted in the book. After exposing some questions that make it possible to evaluate the progress of the community of inquiry, she argues:

Finally, I remind you that the community of inquiry has a moral and political dimension that you must be aware of at all times. (...) If we assume that the purpose of education is the forming of persons - persons of responsibility and integrity, capable of making good judgments - then the community of inquiry becomes a means and an end, satisfying in itself, while at the same time cultivating the traits essential for morally discriminating persons.

In becoming members of a community of inquiry, your students will have the opportunity to develop the virtues of courage, perseverance and self-esteem. (pp. 92-93)

Undoubtedly, this clearly normative conception is compatible with a deep fallibilism, which was defended by Sharp. The compatibility applies in the case of ethical inquiry, which in each situation must seek appropriate 
Gregory, Maughn Rollins \& Laverty, Megan Jane, eds. In community of inquiry with ann Margaret Sharp: childhood, philosophy, and education. New York: Routledge, 2018, Pp. 264.

answers, with a clear awareness that these answers are always fallible and can be modified as a result of one's own action and reflection, and must take into account the point of view of others (Lipman y Sharp, ib., pp. 21-38). This fallibilism does not lead to relativistic or subjectivist positions, but to an intersubjective effort to seek the truth. In communitarian philosophical inquiry, fallibilism is linked to self-correction, which implies procedures of high moral demand, such as tolerance, attentive and intelligent listening, and the demand to offer arguments that support one's own point of view. Cam's "dialogue" with Ann is very clarifying on this topic (pp. 29-38).

In summary, I insist that the community of philosophical community of inquiry is a normative concept that includes some fundamental moral values that, as we have just seen, must be linked to the development of a set of characteristics (that we can also call habits or virtues). The most basic of these fundamental moral values is care, or caring thinking, which receives special attention starting from an important article by Lipman (1995). Splitter points out in his dialogue with Ann that the Community of Dialogue "aims at the transformation of the persons into more reasonable and caring individuals who struggle for a just and ecologically balanced world" (p. 117). Ann's article, edited and enriched by Laverty, advocates for the need to look into the other person's face to "interact responsively and responsibly ... inspired by their vulnerability and suffering" (p. 124). Ann develops the subject of caring thinking from a variety of sources, especially the thoughts of Emmanuel Levinas and also Nussbaum, and concludes that the community of inquiry is moral education inasmuch as it fosters listening, attention to the other, intelligent sympathy, and compassion among students, as well as the cognitive skills of communal ethical inquiry (p. 127).

A second central moral principle in the community of inquiry is the radical commitment to democracy, defined in large part by Dewey's philosophy of democracy and education. Both Glaser's and Ann's articles emphasize that the democratic principle must be that which guides and structures what is done in the classroom, which becomes, in Glaser's words, a space for civic action that 
will have to be transferred into the social life of those children when they become independent adults. It is true that Glaser and Ann do not address the possible paradoxes that occur in the field of compulsory education, caused by the profound asymmetry between students and teachers. Teachers have two advantages that provoke this asymmetry: first, they have a greater mastery of the skills of argumentation that can condition classroom deliberations; second, teachers, in compulsory education, have strong power both in the configuration of classroom activities and in grading students. Taking this asymmetry seriously requires further exploration for a democratic classroom to be credible (García Moriyón, 199).

Not much is said about the complex implications that this asymmetry has for a right exercise of the teacher's role. Some basic and important ideas are usually provided, especially taking as a starting point some classic advice that Ann also gathers in her articles: the teacher must be methodologically strong and philosophically weak (p. 90). That is to say, s/he must guarantee that people behave as expected of them in a community of inquiry, but s/he does not endorse or support any specific philosophical response, evaluating only the quality of the arguments on which they are based. Glaser emphasizes the need to implement democracy, although in her discussion democracy is limited to the classroom as a site of civic action in the service of building a better society (p. 226). Glaser even points out that it is necessary to provide students with opportunities to share their opinions in spheres beyond the community of inquiry and translate them into actions.

However, Jen Glaser and Ann Sharp do not draw a conclusion that seems obvious to me: one does not have to go very far or wait years to put into practice the habits acquired in the community of philosophical inquiry; it is enough to apply it to the school as a whole. The broad movement of democratic schools, already defended by authors such as Lawrence Kohlberg (Kohlberg, Power y Higgins, 1997), Noam Chomsky (2005) and Michael Apple(2007), and put into practice in experiences such as Sudbury Valley School and the long anarchist pedagogical tradition, with Tolstoy's school, Yasnaya Polyana, 
Gregory, Maughn Rollins \& Laverty, Megan Jane, eds. In community of inquiry with ann Margaret Sharp: childhood, philosophy, and education. New York: Routledge, 2018, Pp. 264.

Fauré's La Ruche or Ferrer's Escuela Moderna (García Moriyón, 1986) as good examples. Indeed, the experience Ann relates in her interview with Shea, of being house mother to a group of at-risk teenaged boys who were left to selforganize most of their education, is an example of democratic education that became formative for $\mathrm{P} 4 \mathrm{C}$. These examples remind us that it is possible to organize schools democratically and that such an organization is fundamental to the achievement of a truly democratic education. The fact that we focus on the specific contribution of philosophical reflection in the classroom should not distract us from a broader approach: the relationship between philosophy for children and the wider movement of democratic schools could be very fruitful (Network of Democratic Citizenship Schools, 2017). Thus, promoting the democratization of the whole school from the community of philosophical inquiry in the classroom seems a recommendable option; and the inclusion of the community of philosophical inquiry in democratic schools would enhance what they are already doing.

This reflection leads me to another very interesting part of the book. It is the work by Ann on the educational thought of Nietzsche (pp. 76-88), written in 1975, which was based on her doctoral thesis in 1973. Both Ann's article and Stefano Oliverio's reflections (pp. 63-75) on the subject are very illuminating regarding her understanding of education. She sees in Nietzsche a defender of an exigent education, which aims at overcoming an impoverishing educational system. On the one hand, the Nietzschean image of the child presents us with the innocence of becoming and the capacity for astonishment, which must be preserved; on the other hand, following Nietzsche, she sees in the educational process the effort of self-improvement, which points towards the image of the overman. The teacher demands from the child the effort to overcome him- or herself, to accept the pain of this process, which is nothing but the pain of accepting the consequences of being free. That is why Ann calls the educational process a process of liberation in which the teacher acts as a friend and companion of the children, but also as a person who requires them to take responsibility for their own lives. 
On the other hand, Oliverio rightly points out that Nietzsche does not praise childhood as a specific stage of human life (p. 70), since he proposes overcoming this biological stage in order to pass to the higher state, following the three metaphors: first, the spirit becomes a camel; then the camel becomes a lion; and the lion, finally becomes a child. "Child" is a metaphor of the Overman; the child is the mature human being who has regained the seriousness that he had as a child at play; the child does not follow the morality of common people since that favors mediocrity but instead rises beyond good and evil and above the "herd", the egalitarian human beings of democracy.

However, in both Ann's and Oliverio's articles an interpretation of Nietzsche is offered in a somewhat partial or slightly biased sense. It is true that we can see in Nietzsche a "liberator", but it is also true that in Nietzsche's work there are clearly supremacist and reactionary proposals, with an overman model that is at the very antipodes of P4C (Lukacs, 1967). Although the most modern critical edition of Nietzsche's works has partly corrected this negative view, he is a complex author, who philosophizes "with a hammer" and employs a rhetoric that has made it possible for many people to interpret the very controversial rhetoric of the genealogy of morality in that negative sense and to read him like the two young men in Alfred Hitchcock's film, Rope, who murder a friend of them just to show to their high school philosophy teacher that they are following Nietzsche's ideal of overman.

In any case, Nietzsche's work allows Ann to highlight an aspect of the community of philosophical inquiry as a process of empowerment and liberation in the sense that Nietzsche points out, but without forgetting, as Gert Biesta would say (quoted by Oliverio, p. 65), that the role of the teacher goes beyond being a liberator. Rather s/he is the person who, as an educator, teaches from a clearly asymmetrical position. The teacher must accompany and guide students, with strong demands in the procedures, but maintaining a poker face with respect to the content, as s/he guides them in their strictly personal process of maturation and growth. For this reason, it is important to complete Nietzsche's reading with Teresa de la Garza's contribution to the book, which 
Gregory, Maughn Rollins \& Laverty, Megan Jane, eds. In community of inquiry with ann Margaret Sharp: childhood, philosophy, and education. New York: Routledge, 2018, Pp. 264.

speaks of education for liberation in reference to children and women (pp. 133134).

De la Garza (pp. 133-144) and also Ann (pp. 174-185) emphasize Paulo Freire's approach. On the one hand, no one liberates anyone else, but human beings liberate themselves in community, since the liberation of each one is linked to the freedom of the others. Moreover, both de la Garza and Ann take up an important concept of Freire: the culture of silence. It is the culture of those who, in a permanent situation of exclusion, do not even speak, especially women and children, but also Blacks, Indians, Hispanics ..., the wretched of the earth. Ann expresses it well:

This culture is comprised of people who feel that they have no power to control their daily lives. They know that this is not how it ought to be [...]. Persons are beings who should be able to exercise self-control and determine for themselves how they want to spend their waking hours. (1997, p. 176)

Reflection on the culture of silence is central to Ann's article in Part V, dedicated to religion, spirituality, and aesthetics in the community of philosophical inquiry. Indeed, with a Catholic education, although far removed from official Catholicism, Ann confers special importance to the religious dimesion of education, dedicating several articles to it (unfortunately none of them included in the book), but linked to the aesthetic and spiritual dimension of the community of philosophical inquiry (Sharp, 1994).

Shea offers a valuable chapter in which he addresses this topic and mentions four possible levels of relationship between religion and the community of philosophical inquiry that appear in Ann's work: a) religious issues can be discussed with the community's own procedures with many good examples (Gregory and Oliverio, 2018; Hannam and Biesta, 2019); b) concepts such as hope, trust and love, important in religious contexts, are concepts that are addressed in philosophical dialogue; c) classroom philosophical inquiry is itself religious, insofar as it represents a unifying ideal for a democratic society as proposed by Dewey; and d) the practice of community philosophical dialogue in the classroom is a work of art and provides an aesthetic experience (p. 163). 
Although the subject needs a broad treatment because it points to the most profound experience that a community of philosophical inquiry can provide, I think it is enough in this brief review to reproduce a quote from Ann herself, which includes Shea, in which, moreover, the influence of Dewey on Ann's reflections is clear:

John Dewey made a very suggestive remark in his work $A$ Common Faith that each time a community gets together to engage in deliberation, active inquiry into matters of importance, they are engaging in a ritual, a ritual that celebrates the ideals of goodness, truth, and beauty. These ideals do not exist somewhere in another world but are human projections that regulate our inquiry and motivate us to move the actual (that which is) to what we think "ought to be", a world in which the ideals are incarnate. This movement towards the ideal is God, or, better yet, what Mary Daly calls "godding" (p. 165; Sharp, 1997).

This passage makes clear something that I have previously maintained: Ann's whole proposal, like Lipman's, is a regulatory or normative proposal. Her effort is directed towards an ideal that transcends the world as it is and projects us into the world as it ought to be. Importantly, she invites us not to postpone this duty, but to make it present, to prefigure it in each session of philosophical dialogue, transformed into a work of art and aesthetic experience. This prefiguration is what will help children and teachers to interiorize a mode of behavior that demands in each moment of life to come as close as possible to that vital fullness: that each situation be interesting and enriching in itself, so that in the end we can say that it was really worth being active participants in that experience.

Taking a metaphor that Ann herself uses in the article "Silence and Speech in Pixie" (pp. 174-185), the reading of this book is like a kiss, an anointing sign. "Like Sleeping Beauty, Brian awakens from the world of silence to the world of silence and speech, of conversation and dialogue. He chooses to resume speaking to other people" (p. 183). And we, awoken like Brian and Sleeping Beauty, choose also to speak again with others, first with all those who share a similar pedagogical ideal, then with the rest of the educational community and with the whole of society. 
Gregory, Maughn Rollins \& Laverty, Megan Jane, eds. In community of inquiry with ann MargaretSharp: childhood, philosophy, and education. New York: Routledge, 2018, Pp. 264.

referencias

Apple, M.W. y Beane, J.A. (1997). Escuelas democráticas. Madrid: Morata.

Chomsky, Noam (2003). Peregrín Otero, Carlos (ed.). Sobre democracia y educación : escritos sobre ciencia y antropología del entorno cultural. Barcelona. Paidós.

García Moriyón, F. (Ed.) (1986) Escritos anarquistas sobre educación. Zero. Madrid.

García Moriyón, F. (Ed.) (1999). Profesores y alumnos: una relación desigual. En Melero Martínez, J., Miranda Alonso, T. y Blanco Mayor, C. (Coord.) Filosofía y Educación: IV Encuentro Hispano-Portugués de Profesores de Filosofía para Niños Albacete. Univ. Castilla La Mancha. pp. 37-42.

García Moriyón, F. (Ed.) (2002) Matthew Lipman: Filosofía y educación. Madrid. Ed. De la Torre, 2002.

Gregory M.R. \& Oliverio, S. (2018) Philosophy for/with Children, Religious Education and Education for Spirituality. Steps Toward a Review of the Literature. In Ellen Duthie, E., García Moriyón, F. \& Robles Loro, R. (eds.), Parecidos de familia. Propuestas actuales en Filosofía para Niños / Family resemblances. Current proposals in Philosophy for Children. Madrid, Spain: Anaya. pp. 279-296 (2018).

Hannam, P. \& Biesta, G. (2019): Religious education, a matter of understanding? reflections on the final report of the Commission on Religious Education, Journal of Beliefs \& Values.

Kohlberg, L., Power, F.C. y Higgins, A. (1997): La educación moral según Lawrence Kohlberg. Barcelona. Gedisa.

Lipman, Matthew (1995). Caring as Thinking. Inquiry: Critical Thinking Across the Disciplines, Autumn, Vol. 15, No. 1, pp, 1-13.

Lipman, M. and Kennedy, D. (2010): Ann Sharp's contribution. A conversation with Matthew Lipman. childhood and philosophy, 6 (11): 11-19.

Lipman, M, y Sharp, Ann (1988). Investigación ética. Madrid. Ed. De la Torre.

Lukacs, Georg (1967 [1954]). El asalto a la razón Barcelona. Grijalbo. Cap. III. Nietzsche. Fundador del irracionalismo en el periodo imperialista.

Nietzsche, F. (2019). La genealogía de la moral: un escrito polémico. Madrid. Alianza Editorial.

Sharp, A. M. (1997): The Sacred as Relationship in the Community of Inquiry. In H. Pálsson; B. Siguroardóttir \& B. Nelson (Eds.): Philosophy for Children on Top of the World. Proceedings of the Eight International Conference on Philosophy with Children. University of Akureyri, Iceland

Network of Democratic Citizenship Schools (2017) Schools \& Democracy No. 01 I 2017. Consultado en <http://democraticschools.ecos.pt/magazine-sd/>

Rondhuis, N.T.W. (2005). Philosophical Talent: Empirical investigations into philosophical features of adolescents' discourse. Utrecht University Repository <https://dspace.library.uu.nl/handle/1874/7311>

received en: 22.08 .2019

approved en: 02.09.2019 